\title{
KOMPOSISI JENIS DAN STRUKTUR KOMUNITAS IKAN DI PADANG LAMUN PERAIRAN BANABUNGI KEC. KADATUA KABUPATEN BUTON SELATAN
}

\section{The Species Composition and Fish Community Structure in The Seagrass of Banabungi Village Waters, Kadatua Sub-District, Buton Selatan Regency}

\author{
Wa Ode Era Nurcaya ${ }^{1}$,Wa Nurgayah ${ }^{2}$, dan Hasnia Arami $^{3}$ \\ ${ }^{1}$ Mahasiswa Jurusan Ilmu Kelautan, \\ Fakultas Perikanan dan Ilmu Kelautan, Universitas Halu Oleo. \\ J1. H.E.A Mokodompit Kampus Hijau Bumi Tridharma Anduonohu Kendari 93232, Telp/Fax: (0401) 3193782 \\ ${ }^{2}$ Surel: nurgayah_fish@yahoo.com \\ ${ }^{3}$ Surel: arami79-firazufpsd@yahoo.co.id
}

\begin{abstract}
Abstrak
Salah satu peran ekologis padang lamun adalah sebagai habitat ikan. ikan memanfaatkan padang lamun untuk mencari makan, memijah, atau sebagai tempat untuk berlindung. Penelitian ini bertujuan untuk menganalisis komposisi jenis, keanekaragaman, keseragaman, dan dominansi ikan di daerah padang lamun. Penelitian ini dilaksanakan di perairan Desa Banabungi Kecamatan Kadatua Kabupaten Buton Selatan pada bulan September sampai Oktober 2018. Ikan yang ditangkap menggunakan jaring insang dan bubu ukuran mata jaring 1,5 inci dan ukuran bubu $2 \mathrm{~m}$ lebar $1 \mathrm{~m}$, dan tinggi 25 $\mathrm{cm}$. Data penelitian dianalisis dengan melihat komposisi jenis, keanekaragaman, keseragaman, dan dominansi. Selama penelitian ditemukan 328 ekor ikan terdiri dari 18 spesies dan 10 famili. Nilai keaenekaragaman jenis dalam kategori sedang $\left(\mathrm{H}^{\prime}=2,60-2,78\right)$, keseragaman jenis tinggi $(\mathrm{E}=0,99)$ dan tidak ada jenis ikan yang mendominansi $(\mathrm{C}=0,065$ $0,069)$. Secara umum keseragaman jenis relatif tinggi, dan menunjukan bahwa tidak ada jenis yang mendominansi serta penyebaran merata.
\end{abstract}

Kata kunci : komposisi jenis, keanekaragaman, keseragaman,dominansi,lamun, dan Banabungi.

\begin{abstract}
One of the ecological roles of seagrass beds is a habitat for marine fishes. The seagrass beds have several functions including as a feeding area for marine fishes, as spawning and nursery habitats or as a shelter from predators' threat. This research was aimed to analyze the composition of species, diversity, uniformity, and domination of marine fishes in the area of seagrass beds. This research was conducted in the waters area of Banabungi Village, Kadatua Sub-district, Buton Selatan Regency, from September to October 2018. The marine fishes were caught by using gillnet and fish trap (locally known as Bubu). The gill net was about 1.5 inches in size and $2 \mathrm{~m}$ wide while the 'Bubu' was about $1 \mathrm{~m}$ (wide) and 25 $\mathrm{cm}$ (high). The data from this research were analyzed by looking at the composition of species, diversity, uniformity, and domination of marine fishes. During the study, it found 328 marine fishes consisted of 18 species and ten families. The diversity index value is in the moderate category $\left(\mathrm{H}^{`}=2.60-2.78\right)$ while the type of uniformity is high $(\mathrm{E}=0.99)$, and there are no fishes that dominate the area $(\mathrm{C}=0.065-0.069)$. In general, the uniformity of fishes is relatively high. There was no domination of specific marine fishes as well as their distribution were spreading evenly.
\end{abstract}

Keywords:Banabungi, diversity, dominance, seagrass, species composition,uniformity

\section{Pendahuluan}

Ekosistem Padang lamun (seagrass) merupakan salah satu ekosistem perairan tropis yang sangat berperan dalam kehidupan berbagai jenis biota laut khususnya berbagai jenis ikan yang memanfaatkannya baik sebagai daerah asuhan dan perlindungan (nursery ground), dan sebagai tempat memijah (spawning ground) maupun sebagai padang penggembalaan atau tempat mencari makan (feeding ground). berbagai jenis biota laut seperti ikan, moluska, echinodermata, krustasea,reptillia,cacing,serta mamalia laut. (Dahuri, 2003).
Keragaman spesies ikan di padang lamun disebabkan karena area padang lamun terdapat kelimpahan makanan, tempat pembesaran, dan nilai tutupan lamun dapat memberikan tempat untuk bersembunyi dari predator. (Manik, 2011). Kelompok ikan dalam menggunakan area padang lamun dapat bersifat sementara dan permanen, terutama dari kelompok ikan komersial seperti Sillago sihama, Gerres erythrurus, Sillago aeolus, Sardinella Albella, Thryssa hamiltonii, Plotosus lineatus, Gerres oyena dan Atherinomorus duodecimalis (Adrim, 2006). 
Peranan ekosistem padang lamun sebagai daerah perlindungan bagi komunitas ikan berkaitan erat dengan vegetasi lamun jenis yang mendominasi. Karakteristik kanopinya berfungsi sebagai peredam gelombang dan arus sekaligus memberikan perlindungan bagi anakan ikan (juwana) dari serangan predator. Padang lamun digunakan oleh ikan-ikan juwana dalam cara yang berbeda, umumnya sebagai tempat mencari makan, tempat berlindung dari predator, mengurangi kompetisi, dan meningkatkan ketersediaan makanan sehingga membangun konektivitas dengan ekosistem lainnya (Latuconsina dan Ambo-Rappe, R 2012).

Komposisi jenis komunitas ikan di ekosistem padang lamun adalah kumpulan dari berbagai spesies ikan yang hidup dan memanfaatkan ekosistem padang lamun secara bersama dan mempunyai struktur fisik dan struktur biologis yang merupakan indikator terhadap pengaruh perubahanperubahan yang terjadi. Keanekaragaman spesies dalam komunitas ikan di ekosistem padang lamun semakin berkurang apabila kondisi dan kualitas ekosistem padang lamun semakin memburuk. Tidak semua spesies ikan mampu beradaptasi dan bertahan hidup dalam kondisi habitatnya, misalnya pada ekosistem padang lamun yang tidak stabil/terganggu, maka tingkat resistensi setiap spesies ikan akan berbeda pula (Manik, 2011).

Desa Banabungi memiliki area padang lamun yang cukup luas, dan keanekaragaman hayati yang memiliki nilai ekonomis di dalamnya seperti ikan. Penelitian ini bertujuan untuk mengetahui Komposisi jenis ikan padang lamun dan, Struktur komunitas ikan yang meliputi indeks keseragaman, keanekaragaman dan dominasi ikan pada penutupan lamun di perairan Banabungi.

\section{Bahan dan Metode}

Penelitian ini dilaksanakan pada bulan September - Oktober 2018. Pengambilan sampel lamun dan analisis kualitas air, serta identifikasi jenis ikan dilakukan di perairan Banabungi kec. Kadatua Kab. Buton Selatan (Gambar 1).

Penentuan lokasi penelitian dibagi dalam tiga stasiun ditentukan berdasarkan pengamatan pendahuluan dengan melihat kondisi lamun sehingga dapat mewakili secara ekologis. Stasiun I, berada di sebelah Timur dengan vegetasi tutupan lamun sedang, stasiun ini berdekatan dengan dermaga, (5'30'20.58' LS $/ 122^{\circ} 31^{\prime} 30.58^{\prime \prime}$ BT). Stasiun II, tutupan lamun rapat, stasiun ini memiliki vegetasi

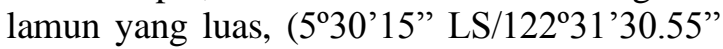
BT). Stasiun III, tutupan lamun jarang, stasiun ini beradah dianatara lamun dan karang, (5³0’20." LS/122 $\left.28^{\circ} 52^{\prime \prime} \mathrm{BT}\right)$.

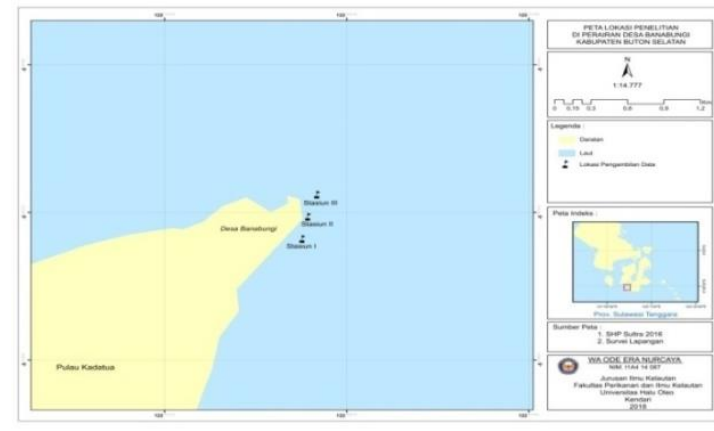

Gambar 1. Peta Lokasi Penelitian

Prosedur penelitian meliputi tahap persiapan, penentuan stasiun penelitian, kepadatan lamun, komposisi jenis, dan struktur komunitas ikan yang ada pada ekosistem padang lamun.

Pengambilan data tentang kondisi tutupan lamun diperoleh dengan menggunakan transek kuadrat yang berukuran $1 \mathrm{~m}$ x $1 \mathrm{~m}$. Pengamatan persen tutupan lamun dilakukan dengan mengamati lamun dalam transek pada tiap titik pengamatan. Setiap stasiun ditetapkan transek garis yang diletakkan tegak lurus dari garis pantai ke arah laut sepanjang $100 \mathrm{~m}$. Jarak antara setiap kuadrat transek disesuaikan untuk tiap stasiun yaitu $10 \mathrm{~m}$, pengamatan persen tutupan lamun dilakukan sebanyak 3 kali ulangan pada tiap stasiun.

Pengambilan data ikan dilakukan dengan menggunakan metode deskriptif eksploratif, yaitu melakukan survey dan menjadi dasar dalam mengambil kebijakan atau penelitian lanjutan. Penelitian deskriptif yang bersifat eksploratif bertujuan untuk menggambarkan keadaan atau status yang ada, salah satu metodenya yaitu menggunakan jaring insang dan bubu.

Jaring insang yang digunakan memiliki panjang mesh size yaitu $30 \mathrm{~m}$ dan tinggi jaring setiap mesh size yaitu $2 \mathrm{~m}$, ukuran mata jaring 1,5inci. Pengambilan sampel dilakukan sebanyak sebanyak 6 kali selama satu bulan. Ikan ditangkap dengan jaring insang yang dipasang pada pagi hari pada saat air laut 
pasang menjelang surut dengan 2 kali sapuan diatas hamparan lamun pada jarak 50 sampai 80 dari garis pantai. Ikan-ikan yang tertangkap dilakukan identifikasi dan tabulasi jenis dengan menggunakan buku identifikasi ikan (Kuiter dan Taonozuka, 2001).

Hasil yang didapatkan selanjutnya dipilah dan diidentifikasi, serta dihitung jumlah individu per jenis. Data yang didapatkan kemudian diolah atau dianalisis untuk menggetahui jenis ikan di hamparan lamun tersebut, juga dibuat dalam bentuk tabel dan grafik.

Adapun pemasangan bubu dioperasikan sehari kemudian setelah pemasangan jaring bubu yang digunakan terbuat dari bambu ( Gambar 5). Yang dianyam berbentuk segi empat persegi panjang berukuran panjang $2 \mathrm{~m}$, lebar $1 \mathrm{~m}$ dan tinggi $25 \mathrm{~cm}$. Proses pemasangan Bubu (setting) pada siang hari sekitar (Pukul 13.00 WITA) dengan lama perendaman selama dua hari, kemudian di waktu yang sama kembali diangkat (hauling) pada siang hari sekitar (pukul 13.00 WITA). Ikan yang tertangkap pada setiap trip di setiap stasiun pengamatan diidentifikasi dengan menggunakan buku identifikasi ikan (Kuiter dan Taonozuka, 2001).

Pengukuran kualitas perairan dilakukan pada setiap stasiun pengamatan yang meliputi pengukuran salinitas, suhu, kecepatan arus, $\mathrm{pH}$, DO dan pasang surut. Parameter kualitas perairan selanjutnya diamatai secara langsung di lapangan. Pengukuran kualitas perairan dilakukan sebanyak 3 kali ulangan pada tiap stasiun. Analisis DO (Oksigen terlarut) dianalisis di Laboratorium penguji, Fakultas Perikanan dan Ilmu Kelautan, Universitas Halu Oleo, Kendari.

\section{Analisis Data}

Persentase tutupan lamun dengan menggunakan persamaan (Setyobudiandi et al., 2009).

$C=\frac{\sum(C i)}{N}$

Keterangan :

$\mathrm{C}=$ Persen penutupan lamun pada setiap subtasiun

$\mathrm{Ci}=$ Persentase penutupan lamun jenis ke $-i$ pada tiap plot transek

$\mathrm{N}=$ Jumlah plot transek disetiap substasiun
Table 1. Kategori Persen Tutupan Lamun.

\begin{tabular}{cc}
\hline Syarat Penutupan & Kesimpulan \\
\hline $\mathrm{C}>5 \%$ & Sangat jarang \\
$5<\mathrm{C}<25$ & Jarang \\
$25<\mathrm{C}<50 \%$ & Sedang \\
$50 \leq \mathrm{C} \leq 75 \%$ & Rapat \\
$\geq 75 \%$ & Sangat rapat \\
\hline
\end{tabular}

Sumber: Kepmen LH Nomor 200 Tahun 2004

Komposisi spesies adalah perbandingan antara jumlah individu setiap spesies dengan jumlah individu seluruh spesies yang tertangkap, dengan formula yang dimodifikasi dari Fachrul (2007) :

$\mathrm{Ks}=\frac{n i}{N}$

Keterangan:

$\mathrm{Ks}=$ Komposisi spesies ikan $(\%)$,

$\mathrm{ni}=$ Jumlah individu setiap spesies ikan,

$\mathrm{N}=$ Jumlah individu seluruh spesies ikan

Indeks keanekaragaman adalah nilai

yang menjelaskan tingkat keseimbangan keanekaragaman dalam suatu pembagian jumlah individu tiap spesies. Rendah atau tingginya keanekaragaman spesies ikan dapat dilihat dengan menggunakan indeks keanekaragaman. Nilai indeks keanekaragaman Shannon (H') menurut Odum (1993) dihitung menggunakan formula: $\mathrm{H}^{\prime}=-\sum_{i=1}^{n}\{\mathrm{pi} \ln \mathrm{pi}\}, \mathrm{pi}=\mathrm{ni} / \mathrm{N}$

Keterangan:

$\mathrm{H}^{\prime}=$ Indeks keanekaragaman ShannonWienner

$\mathrm{Pi}=$ Perbandingan antara jumlah individu spesies jenis ke-i dengan jumlah total individu spesies $(\mathrm{ni} / \mathrm{N})$

$\mathrm{ni}=$ Jumlah individu spesies ke-i

$\mathrm{N}=$ Jumlah total indidvidu semua spesies

Penentuan kriteria:

$\mathrm{H}^{\prime}<1=$ Keanekaragaman rendah

$1<\mathrm{H}^{\prime}<3=$ Keanekaragaman sedang

$\mathrm{H}^{\prime}>3=$ Keanekaragaman tinggi

Indeks keseragaman adalah indeks yang menunjukan sebaran spesies disemua stasiun merata atau tidak dan mengetahui keseimbangan individu dalam keseluruhan populasi. Persamaan indeks keseragaman ikan dapat dihitung dengan rumus (Odum, 1993).

$\mathrm{E}=\frac{H^{\prime}}{H \max }$

Keterangan:

$\mathrm{E}=$ Indeks keseragaman

$\mathrm{H}^{\prime}=$ Indeks keanekaragaman ShannonWienner

$\mathrm{H}_{\max }=\mathrm{Ln} \mathrm{s}$

$\mathrm{s} \quad=$ Jumlah spesies dalam komunitas 
Menurut Krebs (1989), indeks keseragaman berkisar antara 0-1

$\mathrm{E}<0,4=$ Keseragaman spesies rendah $0,4 \leq \mathrm{E} \leq 0,6=$ Keseragaman spesies sedang $\mathrm{E}>0,6=$ Keseragaman spesies tinggi

Nilai indeks dominansi (C) digunakan untuk melihat dominansi satu jenis ikan dalam komunitasnya. Formula indeks keseragaman menurut Odum (1993), yaitu:

$\mathrm{C}=\sum_{i=1}^{n}\{\mathrm{ni} / \mathrm{N}\}^{2}$

Keterangan :

$\mathrm{C}=$ Indeks Dominansi Simpson,

$\mathrm{N}=$ Jumlah individu seluruh spesies,

$\mathrm{ni}=$ Jumlah individu dari spesies ke-i

Penentuan kriteria:

$0<\mathrm{C}<0,4=$ Dominansi spesies rendah

$0,4<\mathrm{C} \leq 0,6=$ Dominansi spesies sedang

$0,6 \mathrm{C}>1=$ Dominansi spesies tinggi

\section{Hasil dan pembahasan}

Pulau Kadatua memiliki iklim tropis umumnya sama dengan iklim Kabupaten Buton yaitu musim Timur dan musim Barat. Topografi perairan pulau Kadatua khususnya Desa banabungi pada tiap stasiun landai dan didominasi oleh substrat pasir dengan hamparan perairan dangkalnya sebagian besar ditiupi oleh padang lamun. Kegiatan penangkapan ikan di daerah ini dilakukan dengan menggunakan alat tangkap jaring, bubu, dan pancing.

Persen tutupan lamun akan semakin tinggi bila kondisi lingkungan perairan tempat lamun tumbuh dalam keadaan baik. Perairan Kadatua yang relatif dangkal dan jernih sangat mendukung tutupan lamun. Hamparan perairan Kadatua sebagian besar terdapat ekosistem lamun yang membentuk vegetasi campuran di setiap stasiun pengamatan. Jenis lamun yang ditemukan yaitu T. hemprichii, E. acoroides, ,H. pinifolia, dan $H$. ovalis. Persen tutupan lamun dipengaruhi oleh faktor-faktor tempatnya tumbuh, yaitu kedalaman, kecerahan air, dan tipe substrat (Kiswara, 1997). Menurut kategori persen tutupan lamun (Kepmen LH nomor 200 Tahun 2004) stasiun I memiliki presentase penutupan lamun sedang yaitu $36,07 \%$, stasiun II memiliki presentase penutupan lamun rapat yaitu $58,73 \%$ sedangkan untuk stasiun III memiliki presentase penutupan lamun yang jarang yaitu $24,95 \%$.

Jenis lamun T. hemprichii memiliki, presentase tutupan pada keseluruhan stasiun.
T. hemprichii merupakan jenis lamun yang ditemukan tumbuh pada daerah substrat berlumpur berdasarkan pengamatan secara visual tipe substrat di lokasi penelitian yang dicirikan oleh pasir berwarna keputihan bertekstur halus, dan bercampur pecahan karang yang telah mati, maka tipe substrat ini menjadi indikator kuat tempat tumbuh lamun jenis $H$. pinifolia dan $T$. hemprichii. Kedua jenis ini dianggap memiliki toleransi yang tinggi untuk hidup dan berkembang di perairan Kadatua, disamping itu stasiunstasiun tersebut keadaan airnya tetap jernih dan penetrasi cahaya matahari mencapai dasar perairan sehingga fotosintesis dapat berlangsung dengan baik.

Secara keseluruhan jenis lamun yang hidup di perairan Desa Banabungi merupakan jenis lamun yang biasa hidup di perairan dangkal dan selalu terbuka pada saat air surut yang mencapai kedalaman kurang dari 1 meter, dan beberapa jenis lamun yang ditemukan dapat hidup diperairan dalam. Distribusi lamun dari arah pantai hingga kearah tubir di perairan kadatua tergolong vegetasi campuran karena lamun yang ditemukan lebih dari satu jenis. Vegetasi campuran tersusun lebih dari dua atau lebih jenis lamun yang tumbuh bersama pada satu habitat dan biasanya terbentuk di daerah subtidal yang dangkal (Azkab, 2006).

Hutomo et al. (1988) menyatakan bahwa tipe padang lamun campuran adalah padang lamun yang terdiri lebih dari satu jenis dan dapat mencapai delapan jenis. Untuk jenis $H$. ovalis tidak hanya ditemukan di daerah dengan substrat pasir dan umumnya tipe tunggal, tetapi juga ditemukan campuran bersama jenis T. Hemprichii. H. ovalis dapat tumbuh di lokasi penelitian karena secara morfologi anatomi akar jenis ini halus seperti rambut tetapi sangat kuat untuk beradaptasi dengan menancapkan tubuh ke dalam substrat (Larkum et al., 1989).

Selama periode penangkapan, jenis ikan yang tertangkap pada ekosistem padang lamun di Perairan Desa Banabungi yaitu 328 individu yang terdiri dari 18 jenis dan 10 famili. Pada stasiun I jenis ikan yang tertangkap sebanyak 108 individu dan 16 jenis, pada stasiun II jenis ikan yang tertangkap sebnyak 125 individu dan 17 jenis, sedangkan pada stasiun III jenis ikan yang tertangkap sebanayak 95 individu dan 15 spesies. 
Tabel 2. Karakteristik Fisika dan Kimia perairan pada setiap Stasiun Penelitian

\begin{tabular}{cccc}
\hline $\begin{array}{c}\text { Parameter } \\
\text { Perairan }\end{array}$ & Sasiun I & Stasiun II & Stasiun III \\
\hline suhu & $30^{\circ} \mathrm{C}$ & $30^{\circ} \mathrm{C}$ & $31^{\circ} \mathrm{C}$ \\
salinitas & $32 \mathrm{ppt}$ & $32 \mathrm{ppt}$ & $32 \mathrm{ppt}$ \\
$\mathrm{pH}$ & 7 & 7 & 7 \\
$\mathrm{DO}$ & 6,97 & 6,77 & 6,56 \\
Arus & $0,52 \mathrm{~m} /$ detik & $0,28 \mathrm{~m} /$ detik & $0,25 \mathrm{~m} /$ detik \\
Kecerahan & $100 \%$ & $100 \%$ & $100 \%$ \\
kedalaman & $2,5 \mathrm{~m}$ & $2 \mathrm{~m}$ & $3 \mathrm{~m}$ \\
\hline
\end{tabular}

Hasil penelitian yang dilakukan selama bulan September-Oktober diperoleh jumlah total individu ikan pada stasiun I 108 individu, stasiun II 125 individu, dan stasiun III 95 individu. Pada stasiun I jenis ikan yang dominan tertangkap adalah jenis $L$. lentjan dari Family lethrinidae dengan komposisi jenis $11,11 \%$, S. argenteus dari Family siganidae dengan komposisi jenis $8,33 \%$. Salah satu yang mempengaruhi tinggi rendahnya komposisi jenis ikan yang terdapat di perairan Desa Banabungi yaitu kondisi ekologis perairan itu sendiri, hal ini diduga bahwa makanan seperti lamun yang tebal membuat ikan jenis L. lentjan banyak ditemukan di daerah padang lamun. Hal ini sesuai dengan pernyataan Nanto (2016) jenis ikan L. lentjan banyak ditemukan pada daerah lamun dikarenakan padang lamun dijadikan sebagai tempat mencari makan, berdasarkan hasil analisis isi lambung dari jenis L. lentjan ditemukan lamun.

Kondisi lingkungan yang mendukung seperti suhu, salinitas dan $\mathrm{pH}$ yang mendukung dengan keberadaan ikan ini serta sifat predator sehingga $L$. lentjan dapat dominan pada stasiun I, tingginya presentase jenis L. lentjan disebabkan karena ikan tersebut terdapat hampir merata di semua karakteristik perairan yang berbeda di lokasi penelitian dengan jumlah individu relatif banyak, untuk $S$. argenteus sering tertangkap pada daerah lamun pada setiap titik lokasi penelitian, dapat diartikan bahwa $S$. argenteus sendiri lebih aktif mencari makan pada ekosistem lamun dibandingkan pada daerah lain, belum lagi dengan kondisi perairan Banabungi yang masih cukup subur, karena ditemukanya berbagai jenis ikan yang masih aktif mencari makan, sesuai dengan hasil pengamatan yang dilakukan oleh Rahmawati, $d k k$ (2012) bahwa jenis ikan yang paling melimpah di habitat bervegetasi lamun yaitu Siganus sp.
Komposisi jenis ikan yang paling sedikit tertangkap pada stasiun I yaitu $B$. undulates dari Famili balistidae dengan komposisi jenis $2,77 \%$ dikarenakan jenis Hasil B. undulates menjadikan padang lamun sebagai daerah pengembala atau hanya sebagai daerah persinggahan. Hutomo (1985) menyatakan bahwa beberapa ikan yang menjadikan daerah padang lamun sebagai daerah persinggahan yaitu dari famili Apogonidae, Famili Ostraciidae, dan Balistidae, ikan-ikan tersebut bersifat demersal dan hidupnya di daerah terumbu karang yang menjadikan lamun hanya sebagai daerah pembesaran, pengasuhan dan pengenbala yang bersifat sementara Nagelkerken et al. (2002) juga membuktikan bahwa kelimpahan ikan di terumbu karang merupakan fungsi keberadaan mangrove dan padang lamun sebagai areal asuhan dan pembesaran ikan.

Pengukuran suhu $30-31^{\circ} \mathrm{C}$ pada stasiun penelitian tersebut masih menunjukkan kisaran suhu yang optimal bagi kehidupan ikan. Menurut (Kordi, 2007) bahwa kisaran suhu optimal bagi kehidupan ikan di perairan tropis adalah antara $28{ }^{\circ} \mathrm{C}-$ $32{ }^{\circ} \mathrm{C}$, dimana suhu perairan mempengaruhi seluruh tahapan dalam siklus hidup suatu spesies dan dapat membatasi distribusi spesies tersebut melalui pengaruhnya terhadap kemampuan bertahan, reproduksi, pertumbuhan, dan kompetisi dengan organisme lainnya pada batas toleransi tertentu. Beberapa hasil penelitian menunjukkan bahwa ikan sangat peka terhadap perubahan suhu. Sesuai dengan pernyataan (Rasyid 2010) bahwa, Suhu optimal bagi ikan $S$. argenteus adalah $25-$ $34{ }^{\circ} \mathrm{C}$. Hasil pengukuran suhu berada dalam kisaran $30-31^{\circ} \mathrm{C}$, suhu di lokasi penelitian mendukung kehidupan dan penyebaran organisme. 


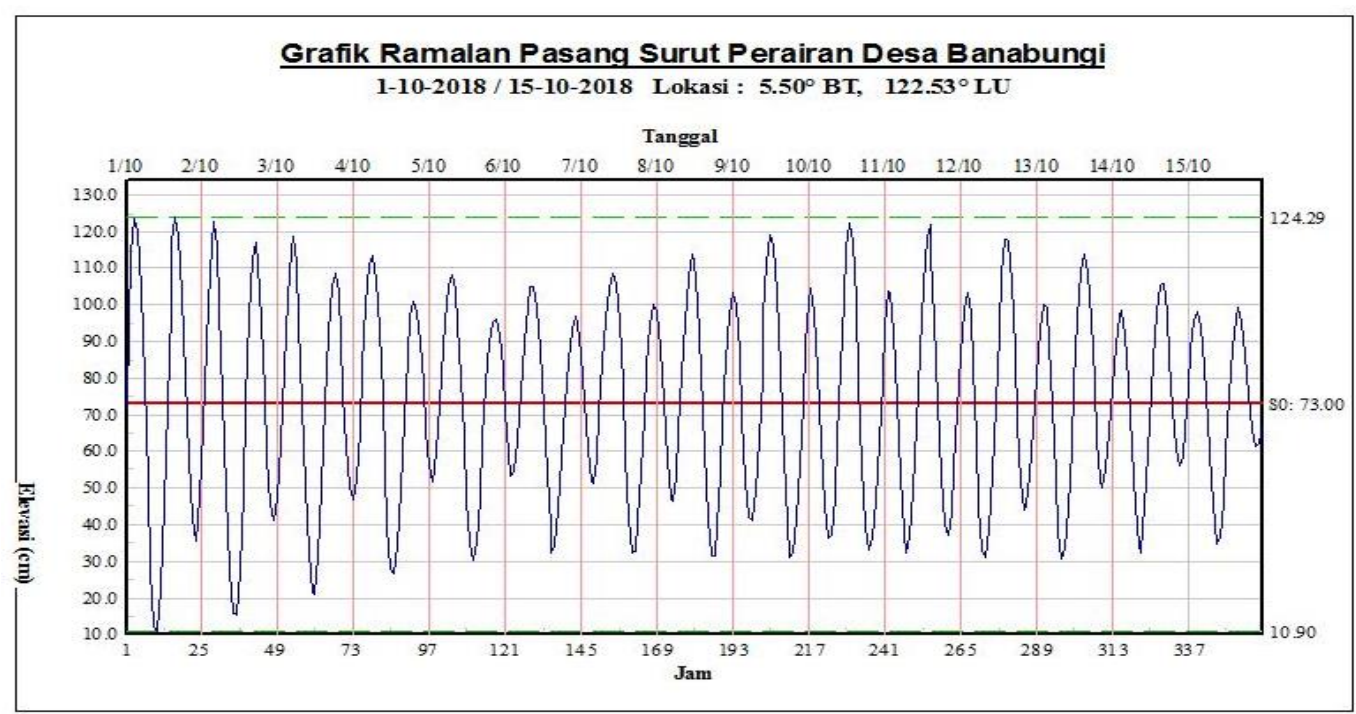

Gambar 1. Grafik Pasang Surut (cm) pada Setiap Stasiun Penelitian.

Pada stasiun II komposisi jenis ikan yaitu $S$. spinus dari Famili siganidae dengan komposisi jenis $11,2 \%$. Berdasarkan hasil pengamatan Siganus sp. merupakan jenis ikan yang paling banyak ditemukan di Perairan Banabungi. Tingginya komposisi jenis Siganus sp. Karena ikan tersebut memiliki kebiasaan hidup bergerombol di daerah padang lamun (Rappe, 2010). Komposisi jenis ikan yang paling sedikit tertangkap pada stasiun II yaitu $R$. verrucosus dari Famili balistidae dengan komposisi jenis 3,2\%. Hal ini disebabkan jenis ini menjadikan daerah padang lamun hanya sebagai daerah pengembala. Hutomo,(1985) ) menyatakan bahwa beberapa ikan yang menjadikan daerah padang lamun sebagai daerah persinggahan yaitu dari famili Apogonidae, Famili Ostraciidae, dan Balistidae, ikan-ikan tersebut bersifat demersal dan hidupnya di daerah terumbu karang. Kedalaman merupakan salah satu factor yang memengaruhi penetrasi cahaya matahari ke dalam perairan

Berdasarkan hasil pengukuran salinitas pada tiga stasiun berkisar antara $32 \mathrm{ppt}$. Kisaran salinitas yang diperoleh pada penelitian ini masih berada pada kisaran yang baik bagi kehidupan organisme. Hal ini diduga karena saat penelitian secara umum mempunyai intensitas curah hujan relatif rendah. Menurut (Rasyid 2010) menyebutkan bahwa ikan S. spinus dapat menoleransi perubahan salinitas sampai 35 ppt. Hal ini sesuai dengan Kepmen Lingkungan Hidup No. 51 Tahun 2004 menyebutkan bahwa standar baku mutu salinitas yang baik untuk kehidupan biota laut yaitu $33-34 \mathrm{ppt}$ pada perairan laut. Salinitas biasanya berkisar antara $34-35$ ppt, karena sering terjadi pengenceran, pengaruh aliran sungai, sehingga salinitas bisa lebih rendah, sebaliknya di daerah dengan penguapan yang sangat kuat, salinitas bisa lebih tinggi Zimmerman (2006).

Stasiun III komposisi jenis ikan yang dominan tertangkap yaitu $S$. spinus dari Famili Siganidae dengan komposisi jenis 9,47\%, Hal ini diduga jenis famili ikan tersebut hidup di lamun. Hutomo,(1985) menyatakan bahwa beberapa ikan yang paling sering terlihat di lamun adalah Famili Singanidae. Dan pada stasiun III ini terdapat jenis ikan $C$. Kleinii dari famili Chaetodontidae dengan komposisi jenis $7,36 \%$, jenis ikan ini hanya ditemukan pada stasiun III karena stasiun tersebut sangat dekat dengan daerah terumbu karang jenis ikan $C$. kleinii merupakan penghuni terumbu karang, C. kleinii atau biasa disebut ikan kepe-kepe. Termasuk dalam kelompok omnivora (pemakan segela) termasuk alga. Hal ini sesuai dengan pernyataan Kuiter (1992). Menyatakan bahwa ikan kepe-kepe ini aktif siang hari mencari tempat berlindung yang dekat dengan terumbu karang ikan ini memiliki mulut yang berukuran kecil dan agak memanjang yang membantu dalam mengambil makanannya. Mereka memakan polip karang, alga, plankton, dan invertebrata lainnya. Keberadaanya di daerah padang lamun dikarenakan pada stasiun III tersebut sangat dekat dengan daerah terumbu karang. 
Tabel 3. Persen Tutupan Lamun pada Tiap Stasiun Penelitian

\begin{tabular}{ccccc}
\hline \multirow{2}{*}{ No } & \multirow{2}{*}{ Jenis Lamun } & \multicolumn{3}{c}{ Peresen Tutupan Lamun (\%) } \\
\cline { 2 - 5 } & Enhalus acoroides & 18,95 & 19,37 & Stasiun III \\
\hline 1. & Thalassia hemprichii & 17,12 & 24,58 & 8,58 \\
\hline 2. & Halodule pinifolia & - & 9,16 & 4,66 \\
\hline 3. & Halophila ovalis & - & 5,62 & 3,91 \\
\hline 4. & Rata-rata & 36,07 & 58,73 & 24,95 \\
\hline & Kategori & sedang & rapat & jarang \\
\hline
\end{tabular}

Tabel 4. Struktur Komunitas Ikan di Perairan Desa Banabungi

\begin{tabular}{lll}
\hline \multicolumn{1}{c}{ Family } & \multicolumn{1}{c}{ Spesies } & \multicolumn{1}{c}{ Indonesia } \\
\hline Balistidae & $\begin{array}{l}\text { Balistapus undulatus } \\
\text { Rinecanthus verrucosus }\end{array}$ & $\begin{array}{l}\text { Ikan Triger, Pogo*,papa kulu** } \\
\text { Ikan Tiger Segitiga, Pogo } \\
\text { Bulamba*,baidrong** }\end{array}$ \\
\hline Chatodontidae & Chaetodon kleinii & Ikan Kepe-Kepe, Kepe-kepe susu* \\
\hline Holocentridae & Sargocentron tiereodies & Ikan Bentok Pelagis, Matabala* \\
\hline Labridae & Cheilis tritobatus & Ikan Kaca, Kalolobu*,Susuri** \\
& Cheilis inemis & Ikan Palu Gada, Sohigonggo*, Palu gada** \\
\hline Lethrinidae & Lethrinus harak & Ikan Lencam, Katamba*,katamba** \\
& Lethrinus lentjan & Ikan Lencam, Katamba*, Lencam** \\
& Lethrius ornatus & Ikan Sikuda, Katamba*, Matahari** \\
\hline Lutjanidae & Lutjanus bengalensis & Ikan Batu-batu, Tonto*, Kakap merah** \\
\hline Mullidae & Parupeneus barberius & Ikan Biji Nangka, Tiko*, biji nangka** \\
& Parupeneus pleurostigma & Ikan Biji Nangka, Tiko*, biji nangka** \\
& Parupeneus vanicolensis & Ikan Jagud Kuning, Tiko*, biji nangka** \\
\hline Nemipteridae & Scolopis aneatus & Ikan Pasir, Tonto*,pasir-pasir** \\
\hline Serranidae & Epinephalus merra & Kerapu Macan, Modea*,balong** \\
\hline Siganidae & Siganus argenteus & Baronang, Malalea*,baronang** \\
& Siganus gutatus & Baronang, Malalea*,baronang \\
& Siganus pinus & Baronang, Malaea tantara*,baronang ** \\
\hline Keterangan:*) Nama & Darah di Lokasi Penelitian **) & Djamali dan Genis (1998)
\end{tabular}

Keterangan : *) Nama Daerah di Lokasi Penelitian,**) Djamali dan Genisa (1998)

Hasil pengukuran pasang surut yang dilakukan selama pengamatan memperlihatkan pola pasang surut campuran yang "semi diurnal" yaitu dua kali pasang dan dua kali surut tetapi tinggi pasang surut dalam sehari memiliki tinggi pasang surut yang berfariasi (selama 24 jam). Seperti dinyatakan Unsworth (2007), bahwa sejumlah besar ikan predator masuk ke padang lamun sebagai akibat dari fungsi pasang surut air laut yang mana keanekargaman dan kelimpahan ikan meningkat sesuai peningkatan pasang surut.

Hasil pengukuran rata-rata kecepatan arus di perairan Desa Banabungi pada setiap stasiun berkisar antara $0,25-0,52 \mathrm{~m} /$ detik. Kecepatan arus yang terendah terdapat pada stasiun 1 dan III sedangkan tertinggi pada stasiun II. Pergerakan arus membawa ikanikan masuk ke ekosistem lamun pada saat pasang. Hal ini sesuai dengan yang dikemukakan Supriharyono (2002) bahwa, hewan-hewan air tertentu khususnya ikan, hidupnya keluar masuk kedalam lamun bersamaan arus pasang surut untuk melakukan pemijahan, pengasuhan dan pembesaran atau mencari makan.

Hasil pengukuran $\mathrm{pH}$ dilokasi penelitian tidak memiliki perbedaan terlalu besar pada setiap stasiun yakni diperoleh nilai kisaran $\mathrm{pH}$ 7. Kisaran ini cukup baik untuk kehidupan ikan seperti yang dinyatakan oleh Kordi ( 2007) nilai pH 6,5 9,0 merupakan kisaran $\mathrm{pH}$ optimal bagi pertumbuhan ikan. $\mathrm{pH}$ air mempengaruhi tingkat kesuburan perairan karena mempengaruhi kehidupan jasa drenik. Perairan yang asam akan kurang produktif karena kandungan oksigen terlarutnya rendah, yang berakibat aktivitas pernafasan ikan meningkat dan nafsu makan menurun. 
Beberapa penelitian yang telah dilakukan dibeberapa tempat di perairan Sulawesi Tenggara menunjukan jumlah spesies ikan yang dominan tertangkap di daerah ekosistem lamun yaitu Siganus sp. Di perairan Kendari jenis ikan yang dominan tertangkap pada daerah lamun yaitu $S$. canaliculatus (Rahmawati et al., 2012), di perairan Mola Selatan Wangi-wangi Selatan Kabupaten Wakatobi jenis ikan yang dominan tertangkap yaitu Siganus sp (Nanto, 2016).

Komunitas merupakan agregasi dari interaksi spesies dalam suatu habitat, dimana interaksi antar jenis lebih kompleks dan bervariasi pada suatu komunitas dengan tingkat keanekaragaman tinggi sehingga terjadi perpindahan energi, predasi dan kompetisi, Hasil analisa struktur komunitas ikan yang meliputi Keanekaragaman dan Keseragaman, Dominansi.

Tinggi rendahnya nilai indeks keanekaragaman jenis disebabkan oleh beberapa faktor, diantaranya jumlah jenis dan spesies yang ditemukan. Adanya individu yang ditemukan lebih mendominansi dari individu lainnya, dan kondisi dari ekosistem (padang lamun) sebagai habitat dari fauna. Berdasarkan kriteria indeks keanekaragaman
(Odum, 1993) bahwa, nilai H' > 3,0 maka nilai keanekaragaman tinggi. Nilai keanekaragaman jenis dari setiap stasiun pengamatan di perairan Desa Banabungi berkisar antara 2,60 - 2,78 tergolong sedang yang diduga faktor kondisi lingkungan yang baik untuk ikan-ikan yaitu diantaranya salinitas yang tidak memperlihatkan kisaran yang bervariasi. Salinitas merupakan salah satu faktor pembatas dalam penyebaran ikanikan di perairan Desa Banabungi. Hal ini juga menunjukan kondisi perairan pada lokasi penelitian belum mengalami tekanan ekologis.

Tingginya keanekaragaman di suatu habitat adalah suatu petunjuk tentang beragam jenis dalam suatu komunitas dapat tumbuh berkembang bersama tanpa adanya kondisi yang saling menghambat dan kondisi seperti ini dikategorikan sehat, menyenangkan serta layak untuk beragam jenis tersebut hidup dan berkembang Odum (1993). Sebaliknya, ketika kondisinya menurun menjadi kurang baik atau menjadi lebih buruk, biasanya timbul satu atau lebih jenis yang mendominasi komunitas karena jenis tersebut mampu bertahan dan berkembang, sehingga nilai keanekaragaman jenis menjadi menurun.

Tabel 5. Komposisi jenis Ikan pada stasiun I, II dan III.

\begin{tabular}{|c|c|c|c|c|}
\hline \multirow{2}{*}{ No } & \multirow{2}{*}{ Jenis Ikan } & \multicolumn{3}{|c|}{ Komposisi Jenis \% } \\
\hline & & Stasiun I & Stasiun II & Stasiun III \\
\hline 1. & B. undulatus & 2,77 & 4 & 4,2 \\
\hline 2. & R. verrucosus & - & 3,2 & 3,15 \\
\hline 3. & C. kleinii & - & - & 7,36 \\
\hline 4. & S. tiereoides & 5,55 & 5,6 & 6,31 \\
\hline 5. & C. tritobatus & 5,55 & 4 & 6,31 \\
\hline 6. & C. inemis & 4,62 & 4,8 & - \\
\hline 7. & L. harak & 9,25 & 7,2 & 7,36 \\
\hline 8. & L. leantjan & 11,11 & 8 & 8,42 \\
\hline 9. & L. ornatus & 5,55 & 7,2 & - \\
\hline 10. & L. bengalensis & 6,48 & 5,6 & 6,31 \\
\hline 11. & P. barberius & 5,55 & 4,8 & 6,31 \\
\hline 12. & P. pleurostigma & 4,62 & 4,8 & 7,36 \\
\hline 13. & P. ciliatus & 5,55 & 4 & - \\
\hline 14. & S. aneatus & 5,55 & 5,6 & 6,31 \\
\hline 15. & E. merra & 4,62 & 4,8 & 7,36 \\
\hline 16. & S. argenteus & 8,33 & 8 & 6,31 \\
\hline 17. & S. gutatus & 7,40 & 7,2 & 7,36 \\
\hline 18. & S. spinus & 7,40 & 11,2 & 9,47 \\
\hline
\end{tabular}


Tabel 6. Nilai Keanekargaman, Keseragaman dan Dominansi Komunitas Ikan

\begin{tabular}{ccccccc}
\hline Stasiun & $\begin{array}{c}\text { Jumlah } \\
\text { Family }\end{array}$ & $\begin{array}{c}\text { Jumlah } \\
\text { Spesies }\end{array}$ & $\begin{array}{c}\text { Jumlah } \\
\text { Individu }\end{array}$ & $\mathbf{E}$ & $\mathbf{C}$ & $\boldsymbol{H}^{\prime}$ \\
\hline I & 9 & 16 & 108 & 0.98 & 0.068 & 2.72 \\
II & 9 & 17 & 125 & 0.98 & 0.065 & 2.78 \\
III & 10 & 15 & 95 & 0.99 & 0.069 & 2.68 \\
\hline
\end{tabular}

Famili Siganidae sp, terlihat berasosiasi erat dengan ekosistem lamun pada setiap stasiun. Sesuai hasil penelitian Gillanders (2006) bahwa Siganidae ditemukan lebih menyukai lamun Enhalus acoroides dan Thalassia hemprichii yang memiliki bentuk lebih besar dan lebar. Kondisi ini diduga mampu menyediakan relung ekologik bagi ikan sebagai tempat asuhan dan pembesaran. Hal ini sesuai dengan pernyataan (Latuconsina dan Ambo-Rappe, 2012) bahwa habitat padang lamun dapat dipandang sebagai suatu komunitas. Dalam hal ini berarti padang lamun merupakan suatu kerangka struktural dengan tumbuhan dan binatang yang saling berhubungan. Padang lamun juga dapat dipandang sebagai suatu ekosistem, dalam hal ini berarti antara tumbuhan, binatang, dan lingkunganya saaling berhubungan. Selain padang lamun faktor lain mendukung keberadaan ikan yaitu faktor lingkungan seperti suhu, salinitas, $\mathrm{pH}$, kecepatan arus, kedalaman perairan, dan kecerahan perairan yang mendukung kehidupan organisme khususnya ikan yang berada di daerah padang lamun.

Penyebaran jenis lamun mepengaruhi spesies ikan yang ditemukan karena ikan menjadikan lamun sebagai habitat hidupnya dan lamun memberikan dukungan terhadap kelimpahan ikan (Gillanders, 2006). Padang lamun dengan persentase tutupan tinggi atau rapat menyediakan perlindungan bagi ikan dari serangan predator. Selain itu, kerapatan lamun yang tinggi tentunya meningkatkan luas permukaan atau penutupan lamun bagi pelekatan hewan maupun tumbuhan renik yang merupakan makanan utama bagi ikan di padang lamun (Hemminga dan Duarte, 2000).

Berdasrkan hasil penelitian indeks dominansi (Tabel 4) terlihat bahwa nilai indeks dominansi jenis ikan (C) di Perairan Desa Banabungi masing-masing berkisar stasiun I 0,068 (rendah), stasiun II 0,065 rendah), dan stasiun III 0,069 (rendah). Nilai tersebut menunjukan bahwa dominansi jenis ikan di perairan Desa banabungi dalam kategori rendah. Pengkategorian ini berdasarkan kriteria indeks dominansi Odum (1993),yang menjelaskan indeks dominansi tergantung pada nilai indeks keanekaragaman $\left(\mathrm{H}^{\prime}\right)$, dan nilai indeks keseragmanan (E), jika nilai dominansi rendah maka nilai keanekaragaman dan keseragaman tinggi. Artinya struktur komunitas dalam keadaan stabil.

\section{Simpulan}

1. Komposisi jenis komposisi jenis sebanyak 18 jenis ikan yang bersal dari 10 famili.

2. Indeks keanekaragaman tertinggi terdapat pada lokasi dengan presentase penutupan lamun rapat dengan kisaran nilai indeks keanekaragaman sedang, presentase penutupan lamun sedang dengan kisaran nilai keanekaragaman sedang. Nilai indeks keseragaman yang sama pada presentase tutupan lamun yang sedang dan rapat yaitu dengan kisaran nilai keseragaman tinggi dan lamun yang jarang yaitu indeks keseragaman nilai pada kategori tinggi dan nilai indeks dominansi dengan pada kategori sedang.

\section{Daftar Pustaka}

Adrim, M. 2006. Asosiasi ikan di padang lamun. Oseana. Volume 31(4) : 1-7.

Azkab, M. H. 2000. Produktifitas di lamun. Oseana. Volume 25(1) : 1-11.

Azkab, M. H. 2006. Ada apa dengan lamun. Oseana. Volume 31(3) : 45-55.

Bengen DG, Eidman M, Boer M. 2001. Strukutur komunitas Ikan di Pantai Utara

Kabupaten Subang, Jawa Barat. Jurnal Pesisir dan Lautan 3(3).

Bengen, D. G. 2004. Ekosistem dan sumberdaya alam pesisir dan laut. Sinopsis.

Dahuri, R. 2003. Keanekaragaman Hayati Laut; Aset pembangunan berkelanjutan Indonesia, Jakarta: Gramedia Pustaka Utama.

Fachrul., 2007. Metode Sampling Bioekologi. Penerbit Bumi Aksara. 
Fahmi, dan Yusup, S.D., 2012, Komunitas Padang Lamun dan Ikan Pantai di Perairan Kendari Sulawesi Tenggara, Ilmu Kelautan, 17 (4): 190-198, Lembaga Ilmu Pengetahuan Indonesia, Jakarta.

Heriman, 2006.srtuktur komunitas ikan yang berasosiasi dengan ekosistem padang lamun di perairan Tanjung Merah, Suawesi Tengah.

Hasmin dan athipermula sami,. 2008 struktur kominitas lamun di perairan tanjung tiram ambon.

Hutomo M. 1988. Peranan lamun di lingkungan laut dangkal. Balai Penelitian Biologi Laut, Puslitbang Oseanologi LIPI. Jakarta.

Hutomo, M. 1985. Telaah Ekologi Komunitas Ikan pada Padang Lamun (Seagrass, Anthophyta) di Perairan Teluk Banten. Disertasi. Fakultas Pascasarjana, Institut Pertanian Bogor.

Irwan,Z.,D. 1997. Prinsip-Prinsip Ekologi dan Ekosistem Komunitas dan Lingkungan, bumiaksara.Jakarta $210 \mathrm{Hal}$.

Keputusan Mentri Lingkungan Hidup. 2004. Pedoman Penetapan Baku Mutu Lingkungan. Kantor Menteri Negara Kependudukan dan Lingkungan Hidup 2004. Keputusan Menteri Negara Kependudukan dan Lingkungan Hidup No. 51 Tahun 2004 tentang Baku Mutu Air Laut. Sekretariat Negara, Jakarta.

Kiswara, W. 1997. Struktur komunitas padang lamun perairan Indonesia, Hal. 5361. Prosiding Kongres Biologi XV, 1997, Universitas Indonesia, Jakarta. Lembaga Ilmu Pengetahuan Indonesia-Universitas Indonesia. Jakarta, Indonesia.

Kiswara, W. dan M. H. Azkab. 2000. Spesimen Lamun (Seagrass) yang Tersimpan di Dalam Koleksi Referensi Puslitbang Oseanologi-LIPI, Jakarta. h. 17-33. In H.M.

Kordi, M.G.H. dan A. Tancung. 2007. Pengelolaan kualitas air dalam budidaya perairan. Rineka Cipta. Jakarta. Hlm.:208.

Kuiter RH. 1992. Tropical Reef-Fishes of the Western Pacific, Indonesia and Adajacent Waters. PT. Gramedia Pustaka Utama. Jakarta. 314 pp.

Kuiter, R.H. dan T. Tonozuka. 2001 Indonesian reef fishes. Part 3.
Latuconsina, H. dan Ambo-Rappe, R. 2012, Variabilitas Harian Komunitas Ikan Padang LamunPerairan Tanjung TiramTeluk Ambon Dalam.

Larkum. A.W.D., A.J. Mc Comb and S.A. Shepherd, 1989. Biology ofseagrasses : a treatise on the biology of seagrasses with special reference toAustralian region. Elssier, Amsterdam: 6-73.

Manik, N. 2011. Struktur komunitas ikan di padang lamun Kecamatan Wori, Sulawesi Utara. Osenaologi dan Limnologi di Indonesia.Volume 37(1) : 294.

Nagelkerken I, Roberts CM, van der Velde G, Dorenbosch M, van Riel MC, Cocheret de la Morinière E, Nienhuis PH. 2002. How important are mangroves and seagrass beds for coral-reef fish? The nursery hypothesis tested on an island scale. Marine Ecology Progress Series, 244: 299-305.

Nanto. 2016.“Keanekaragaman Ikan pada Ekosistem Lamun di Perairan Mola Selatan Wangi-Wangi Selatan Kabupaten Wakatobi". Skripsi, FPIK, Manajemen Sumberdaya Perairan. Universitas Halu Oleo. Kendari.

Nontji. 1993. Laut Nusantara. Penerbit Djambatan. Jakarta.

Odum, 1993.Fundamental of Ecology.Gajah Mada University Press.Yogyakarta.

Raharjo. 1980. Struktur komunitas ikan pada padang lamun yang berbeda di Pulau Barrang Lompo. Jurnal Ilmu dan Teknologi Kelautan Tropis. Volume 2(2) : 62-73.

Rahmawati S, Fahmi, dan Deny SY. 2012. Komunitas padang lamun dan ikan di perairan Kendari Sulawesi Tenggara. Jurnal Ilmu Kelautan, 17(4):190-198.

Rappe, R. A., 2010, Struktur Komunitas Ikan Padang Lamun yang Berbeda di Pulau Barang Lompo, Jurnal Ilmu dan Teknologi Kelautan Tropis, 2 (2) : 6273, Ikatan Sarjana Oseanologi Indonesia dan Departemen Ilmu dan Teknologi Kelautan, Fakultas Perikanan dan Ilmu Kelautan Institut Pertanian Bogor, Bogor.

Rasyid JA. 2010. Distribusisuhu permukaanpada musim peralihan BaratTimur terkait dengan fishing ground ikan pelagis kecil di perairan spermondeTorani 
(JurnalIKelautandanPerikanan), 20(1):1-7.

Rudimansyah, yuyus.Pembangunan prototype system besis data dan peramalan arus pasang surut studi kasus teluk Jakarta. Bandung: program studi oseanografi, 2008.

Soegianto A. 1995.Ekologi kuantitatif: metode analisispopulasi dan komunitas. Usaha Nasional,Surabaya. 173p.

Supriharyono,2007. Konservasi Ekosisten Sumberdaya Hayati di Wilayah PesisirLaut Tropis.Jakarta; Gramedia Pustaka Utama.

Unsworth, RK.F. 2007. Aspects of the ecology of IndoPacificseagrass systems. A thesis submitted for thedegree of doctor of philosophy Department ofBiological Science, University of Essex. 200

Zimmerman, R. C. 2006. Light and photosynthesis in seagrass meadows. Hal. 303-321. In Larkum, A. W. D., Robert J.O., C. M. Duarte (Ed.), Seagrasses : biology, ecology, and conservation. Springer. Dordrecht, Netherlands.

Zulkifli, E. 2003. Kandungan zat hara air poros dan air permukaan padang lamun Bintan Timur Riau. Jurnal Natur Indonesia. Volume 52(2) : 139-144. 